\title{
HUMAN GENES ARE IN SILICO POTENTIAL TARGETS FOR RICE miRNA
}

\author{
Aizhan Rakhmetullina, Anna Pyrkova, Dana Aisina, Anatoliy Ivashchenko \\ ${ }^{1}$ Department of Biotechnology, SRI of Biology and Biotechnology Problems, al-Farabi Kazakh \\ National University, Almaty, al-Farabi 71, Almaty, 050040, Kazakhstan \\ ORCID IDs: 0000-0002-0117-7110 (A.K.); 0000-0001-8483-451X (A.P.); 0000-0002-7137- \\ 3408 (D.A.); 0000-0002-7969-2016 (A.I.)
}

Address correspondence to a.iavashchenko@gmail.com.

The author responsible for distribution of materials integral to the findings presented in this article in accordance with the policy described in the Instructions for Authors (www.plantcell.org) is: Anatoliy Ivashchenko (a.iavashchenko@gmail.com).

\section{Abstract}

Exogenous miRNAs enter the human body through food, and their effects on metabolic processes can be considerable. It is important to determine which miRNAs from plants affect the expression of human genes and the extent of their influence. The binding sites of 738 osa-miRNAs that interact with 17508 mRNAs of human genes were determined using the MirTarget program. The characteristics of the binding of 46 single osa-miRNAs to 86 mRNAs of human genes with a value of free energy $(\Delta G)$ interaction equal $94 \%$ to $100 \%$ from maximum $\Delta G$ were established. The findings showed that osa-miR2102-5p, osamiR5075-3p, osa-miR2097-5p, osa-miR2919 targeted the largest number of genes at 38, 36, 23, 19 sites, respectively. mRNAs of 86 human genes were identified as targets for 93 osamiRNAs of all family osa-miRNAs with $\Delta G$ values equal $94 \%$ to $98 \%$ from maximum $\Delta G$. Each miRNA of the osa-miR156-5p, osa-miR164-5p, osa-miR168-5p, osa-miR395-3p, osamiR396-3p, osa-miR396-5p, osa-miR444-3p, osa-miR529-3p, osa-miR1846-3p, osamiR2907-3p families had binding sites in mRNAs of several human target genes. The binding sites of osa-miRNAs in mRNAs of the target genes for each family of osa-miRNAs were conserved when compared to flanking nucleotide sequences. mRNA human genes of osa-miRNAs are candidate genes of cancer, cardiovascular and neurodegenerative diseases.

\section{Introduction}

Plant miRNA (pl-miR) and animal miRNA (an-miR) are exogenous miRNA or xeno miRNA (ex-miR or xe-miR) for humans and do not have distinctive features among themselves. Therefore, in the human body, they will be perceived as the general diversity of the endogenous miRNA (en-miR) of a human, and all human genes can potentially be their targets. The effect of 
ex-miR on human target genes and the consequences of this effect will depend on their concentration and the duration of their presence in the cells. pl-miR can enter the human body through the gastrointestinal tract and spread with blood in combination with proteins or as part of exosomes (Buck et al., 2014; Escrevente et al., 2011; Montecalvo et al., 2012; van der Grein \& Nolte-'t Hoen, 2014). Many studies have shown that miRNAs that enter the gastrointestinal tract with food (dietary miRNA) are then found in various tissues (Chiang et al., 2015; Jonathan et al., 2013; Liang et al., 2015; Stephen \& Snow, 2017; Vaucheret \& Chupeau, 2012; Zempleni et al., 2017; Zhang et al., 2019; Zhang et al., 2012; Zhao et al., 2018). For example, after consumption of a fresh maize diet most zma-miRNAs were detected in the heart, brain, mammary gland, lung, liver, kidney and serum exosomes of pig (Luo et al., 2017). The concentration of pl-miR in different human organs varies and can be compared with en-miR. Some studies have found minor concentrations of pl-miR in humans and animals (Zhang et al., 2016). The inclusion of plmiR into the recipient's organism causes reproducible changes of some properties and physiological processes in it (Cui et al., 2017; Javed et al., 2017; Lang et al., 2019; Vaucheret et al., 2012; Zhang et al., 2012). ex-miR involvement in the regulation of recipient gene expression may affect disease (Chin, Fong \& Somlo, 2016; Gopinath, 2019; Hou et al., 2018; Jones et al., 2016). The program for searching binding sites in target genes can reliably identify pl-miR and an-miR binding sites regardless of the origin of miRNAs (Ivashchenko et al., 2016), which makes it possible to predict the interaction of pl-miR with hsa-mRNA. We studied the possible interactions of pl-miRs with hsa-mRNA genes after pl-miRs have entered the human body. It was also assumed that pl-miRs can circulate in the blood throughout the body in the absence of features restricting their entry into any cell (Wagner et al., 2015). The basis for this assumption is the diversity of the nucleotide composition of hsa-mRNAs, some of which overlap with diverse pl-miRs (Liang et al., 2013; Pirro et al., 2016).

Recently, the miRNAs of plants ingested for food ex-miR have been actively studied in the regulation of vital processes in humans and animals (Arroyo et al., 2011; Liang et al., 2012; Luo et al., 2017; Vaucheret \& Chupeau, 2012; Zhang et al., 2016). It is presumed that ex-miRs regulate cellular function in healthy cells and act as important mediators in the development of animal diseases (Cong et al., 2018; Hoy \& Buck, 2012; Makarova et al., 2016; Rutter \& Innes, 2018). Ex-miRs can function as evolutionary linkers between different species and contribute to signal transmission both within and between species (Arteaga-Vazquez et al., 2006; Axtell, Westholm \& Lai, 2011; Millar \& Waterhouse, 2005; Moran et al., 2017; Zhao, Cong \& Lukiw, 2018). Based on the available data, the authors suggest that such xe-miRNAs contribute to the beneficial properties of medicinal plants (Lukasik \& Zielenkiewicz, 2016; Xie, Weng \& Melzig, 2016), contribute to the negative properties of disease-causing or poisonous plants, and cross- 
link species between kingdoms of living organisms by participating in many of the mechanisms associated with the occurrence and pathogenesis of various diseases (Malloci et al., 2018; Melnik, John \& Schmitz, 2014; Perge et al., 2017; Pogue et al., 2014).

To determine which pl-miRs affect the mRNAs of human genes, we chose osa-miRNAs because rice has the most miRNAs in the plants, and rice is the most common source of human nutrition. Most plants contain well-known miRNAs, which serve as typical regulators of plant growth and development (Bari, Orazova \& Ivashchenko, 2013; Bari et al., 2014, Nair et al., 2010).

\section{Results}

\section{Characteristics of the interaction of single osa-miRNAs with mRNA of human genes}

Currently, 738 miRNAs encoded by the rice genome are known. For these osa-miRNAs, target genes from among 17508 human genes were searched. A total of 82 miRNAs with one to four target genes ware identified (Table S1). miR11339-3p and miR11339-5p; miR1425-3p and miR1425-5p; miR1432-3p and miR1432-5p; miR1870-3p and miR1870-5p; miR2096-3p and miR2096-5p; miR2867-3p and miR2867-5p; and miR390-3p and miR390-5p, originating from the same pre-miRNA, had binding sites in the mRNAs of different genes. The functions of the 162 identified target genes were diverse.

In the group of 49 miRNAs with five or more target genes, there were several miR-3p/miR-5p pairs that originated from the same pre-miRNA (Table S2). The total number of target genes for miRNAs with five or more genes was 479. The number of target genes for miR408-3p, miR5150-3p, miR528-3p, and miR530-3p was comparable to the number of target genes for miR408-5p, miR5150-5p, miR528-5p, and miR530-5p. For miR1847.1-5p, miR1850.1-5p, miR2094-5p, miR2097-5p, miR2102-5p, and miR3979-5p, the set of target genes was significantly larger than that for each corresponding miRNA-3p. Only miR5144-3p had four-fold more target genes compared to the number attributed to miR5144-5p. The miRNAs with the largest number of target genes were miR2102-5p (38 genes), miR5075-3p (36 genes), miR20975p (23 genes), and miR2919 (19 genes). Consequently, at high concentrations, these miRNAs could significantly change the metabolism of recipient human cells.

A total of 641 target genes were identified for 131 single miRNAs, which is approximately $3.7 \%$ of the total number of studied human genes.

Table 1 shows the characteristics of the binding of some osa-miRNAs with mRNAs of human genes. Each of the 35 miRNAs could bind to mRNAs of one target gene, six miRNAs had targets with two genes, and four miRNAs had three target genes with a value $\Delta \mathrm{G} / \Delta \mathrm{Gm}$ equal to 94 $98 \%$. miR2102-5p had 11 target genes with a value $\Delta \mathrm{G} / \Delta \mathrm{Gm}$ of $94-100 \%$, and the free energy of the interaction of the miRNAs with the mRNAs of these genes varied from $-115 \mathrm{~kJ} / \mathrm{mole}$ to -121 
$109 \mathrm{~kJ} / \mathrm{mole}$. The miR2102-5p binding sites were located mainly in the 5'UTR, which suggests that

110 they have a role in the early inhibition of the translation process. However, this property of

111 miR2102-5p indicates the need to control its plant food-derived concentration in the human

112 body. 19 target genes were associated with miR2919. miR5075-3p could bind to three mRNAs at

113 binding sites located in the coding domain sequence and the 5'-untranslated region. The high-

114 affinity binding sites were located in the 5'UTR and CDS of the mRNAs with the $\Delta \mathrm{G} / \Delta \mathrm{Gm}$ value

115 was 94-98\%. 17 miRNA binding sites were located in 5'UTR, 39 in CDS and 33 in 3'-

116 untranslated region. Therefore, monitoring the concentrations of miR2102-5p, miR2919 and

117 miR5075-3p in human biological fluids is also necessary.

\begin{tabular}{|c|c|c|c|c|c|c|}
\hline Gene & osa-miRNA & $\begin{array}{c}\text { Start of site, } \\
\text { nt }\end{array}$ & $\begin{array}{c}\text { Region } \\
\text { of miRNA }\end{array}$ & $\begin{array}{c}\Delta \mathrm{G}, \\
\mathrm{kJ} / \mathrm{mole}\end{array}$ & $\begin{array}{c}\Delta \mathrm{G} / \Delta \mathrm{Gm}, \\
\%\end{array}$ & $\begin{array}{c}\text { Length, } \\
\text { nt }\end{array}$ \\
\hline CPA3 & $\operatorname{miR} 1320-3 p$ & 671 & CDS & -98 & 96 & 21 \\
\hline$P P A P 2 B$ & $\operatorname{miR} 1320-3 p$ & 2135 & 3'UTR & -96 & 94 & 21 \\
\hline CNPY1 & miR1426-5p & 2094 & 3'UTR & -93 & 94 & 21 \\
\hline NSL1 & $\operatorname{miR} 1440-5 p$ & 4601 & 3'UTR & -98 & 94 & 20 \\
\hline PSEN2 & $\operatorname{miR} 1847.1-5 p$ & 1785 & 3'UTR & -108 & 96 & 21 \\
\hline MDN1 & $\operatorname{miR} 1855-3 p$ & 13027 & $\mathrm{CDS}$ & -106 & 94 & 21 \\
\hline KLHDC10 & $\operatorname{miR} 1860-3 p$ & 3134 & 3'UTR & -108 & 96 & 22 \\
\hline TIE1 & $\operatorname{miR} 1860-3 p$ & 3139 & $\mathrm{CDS}$ & -106 & 94 & 22 \\
\hline OSTM1 & miR2093-3p & 848 & $\mathrm{CDS}$ & -93 & 96 & 20 \\
\hline ZNF80 & miR2099-3p & 2562 & 3'UTR & -96 & 94 & 20 \\
\hline SLC $36 A 3$ & miR2099-5p & 2769 & 3'UTR & -100 & 94 & 22 \\
\hline$A F A P 1$ & $\operatorname{miR} 2102-5 p$ & 144 & 5'UTR & -115 & 95 & 20 \\
\hline C19orf6 & $\operatorname{miR} 2102-5 p$ & 193 & $\mathrm{CDS}$ & -115 & 95 & 20 \\
\hline CHSY1 & $\operatorname{miR} 2102-5 p$ & 348 & 5'UTR & -117 & 96 & 20 \\
\hline DIRC2 & $\operatorname{miR} 2102-5 p$ & 233 & $\mathrm{CDS}$ & -117 & 96 & 20 \\
\hline KATNALI & $\operatorname{miR} 2102-5 p$ & 80 & 5'UTR & -117 & 96 & 20 \\
\hline NRID2 & $\operatorname{miR} 2102-5 p$ & 254 & 5'UTR & -117 & 96 & 20 \\
\hline PDAP1 & $\operatorname{miR} 2102-5 p$ & 29 & 5'UTR & -115 & 95 & 20 \\
\hline$P P P 2 R 5 C$ & $\operatorname{miR} 2102-5 p$ & 72 & 5'UTR & -115 & 95 & 20 \\
\hline RHOBTB2 & $\operatorname{miR} 2102-5 p$ & 158 & 5'UTR & -115 & 95 & 20 \\
\hline$U H R F 1 B P 1$ & $\operatorname{miR} 2102-5 p$ & 112 & 5'UTR & -115 & 95 & 20 \\
\hline WT1 & $\operatorname{miR} 2102-5 p$ & 450 & $\mathrm{CDS}$ & -121 & 100 & 20 \\
\hline ZNF442 & $\operatorname{miR} 2866-5 p$ & 1020 & $\mathrm{CDS}$ & -98 & 96 & 20 \\
\hline PCDHB 15 & $\operatorname{miR} 2866-5 p$ & 582 & $\mathrm{CDS}$ & -96 & 94 & 20 \\
\hline GPR20 & $\operatorname{miR} 2867-3 p$ & 455 & $\mathrm{CDS}$ & -106 & 94 & 20 \\
\hline TMEMЗ8А & $\operatorname{miR} 2867-3 p$ & 236 & CDS & -106 & 94 & 20 \\
\hline ATP13A3 & $\operatorname{miR} 2867-5 p$ & 3035 & CDS & -115 & 95 & 22 \\
\hline$H K 2$ & $\operatorname{miR} 2868-5 p$ & 6645 & 3'UTR & -93 & 96 & 20 \\
\hline ZNF395 & $\operatorname{miR} 2870-3 p$ & 863 & $\mathrm{CDS}$ & -100 & 94 & 21 \\
\hline$I Q G A P I$ & $\operatorname{miR} 2876-5 p$ & 1234 & CDS & -102 & 94 & 21 \\
\hline ADAMTS5 & $\operatorname{miR} 2919$ & 471 & 5'UTR & -104 & 96 & 19 \\
\hline$B D N F$ & $\operatorname{miR} 2919$ & 2681 & 3'UTR & -106 & 98 & 19 \\
\hline GPBPIL1 & $\operatorname{miR} 2919$ & 1015 & 5'UTR & -104 & 96 & 19 \\
\hline KIAA1161 & $\operatorname{miR} 2919$ & 3436 & 3'UTR & -106 & 98 & 19 \\
\hline AKAP11 & $\operatorname{miR} 2919$ & 7158 & 3'UTR & -102 & 94 & 19 \\
\hline ATG13 & $\operatorname{miR} 2919$ & 259 & 5'UTR & -102 & 94 & 19 \\
\hline$C 1 D$ & $\operatorname{miR} 2919$ & 543 & 3'UTR & -102 & 94 & 19 \\
\hline$C D C 25 B$ & miR2919 & 661 & 5'UTR & -102 & 94 & 19 \\
\hline$F A M 59 B$ & miR2919 & 257 & 5'UTR & -102 & 94 & 19 \\
\hline$F A M 83 H$ & $\operatorname{miR} 2919$ & 4348 & 3'UTR & -102 & 94 & 19 \\
\hline MINK1 & miR2919 & 4936 & 3'UTR & -102 & 94 & 19 \\
\hline NEUROD2 & miR2919 & 145 & 5'UTR & -102 & 94 & 19 \\
\hline
\end{tabular}




\begin{tabular}{|c|c|c|c|c|c|c|}
\hline OTUD4 & miR2919 & 4235 & 3'UTR & -102 & 94 & 19 \\
\hline PRDM11 & $\operatorname{miR} 2919$ & 8528 & 3'UTR & -102 & 94 & 19 \\
\hline PTGFRN & $\operatorname{miR} 2919$ & 5633 & 3'UTR & -102 & 94 & 19 \\
\hline$R G S 9 B P$ & miR2919 & 2857 & 3'UTR & -102 & 94 & 19 \\
\hline SPRY4 & $\operatorname{miR} 2919$ & 1576 & 3'UTR & -102 & 94 & 19 \\
\hline ZNF304 & $\operatorname{miR} 2919$ & 2752 & 3'UTR & -102 & 94 & 19 \\
\hline ZNF385A & miR2919 & 1388 & 3'UTR & -102 & 94 & 19 \\
\hline KPNA4 & $\operatorname{miR} 2923-5 p$ & 7223 & 3'UTR & -93 & 94 & 22 \\
\hline SHISA6 & miR2925-5p & 71 & CDS & -106 & 94 & 19 \\
\hline SPON1 & $\operatorname{miR} 2925-5 p$ & 93 & 5'UTR & -106 & 94 & 19 \\
\hline ZNHIT2 & $\operatorname{miR} 2925-5 p$ & 559 & $\mathrm{CDS}$ & -106 & 94 & 19 \\
\hline UFSP1 & $\operatorname{miR} 2931-5 p$ & 960 & 3'UTR & -91 & 96 & 20 \\
\hline$I G S F 3$ & miR394-5p & 2007 & CDS & -102 & 94 & 20 \\
\hline PGAPI & $\operatorname{miR} 394-5 p$ & 9153 & 3'UTR & -102 & 94 & 20 \\
\hline ZNF425 & $\operatorname{miR} 3979-5 p$ & 512 & CDS & -102 & 94 & 20 \\
\hline$R B M S 2$ & $\operatorname{miR} 408-3 p$ & 7343 & 3'UTR & -113 & 95 & 21 \\
\hline PPMIF & $\operatorname{miR} 408-5 p$ & 2987 & 3'UTR & -110 & 95 & 21 \\
\hline GPBPIL1 & $\operatorname{miR} 413-5 p$ & 400 & 5'UTR & -102 & 94 & 21 \\
\hline C14orf142 & $\operatorname{miR} 414-5 p$ & 281 & CDS & -104 & 94 & 21 \\
\hline$L M N A$ & $\operatorname{miR} 414-5 p$ & 1902 & CDS & -104 & 94 & 21 \\
\hline ТМЕМЗОВ & $\operatorname{miR} 414-5 p$ & 1700 & CDS & -104 & 94 & 21 \\
\hline$P V R$ & $\operatorname{miR} 415-5 p$ & 5452 & 3'UTR & -104 & 94 & 21 \\
\hline SNAPC1 & $\operatorname{miR} 417-3 p$ & 1169 & $\mathrm{CDS}$ & -98 & 94 & 21 \\
\hline FAM120A & $\operatorname{miR} 418-3 p$ & 1029 & CDS & -98 & 94 & 21 \\
\hline ZNF256 & $\operatorname{miR} 5071-5 p$ & 348 & CDS & -102 & 94 & 21 \\
\hline$N R 2 F 2$ & $\operatorname{miR} 5075-3 p$ & 350 & 5'UTR & -117 & 95 & 21 \\
\hline PARP2 & $\operatorname{miR} 5075-3 p$ & 32 & CDS & -117 & 95 & 21 \\
\hline RPS6KA5 & $\operatorname{miR} 5075-3 p$ & 261 & CDS & -121 & 98 & 21 \\
\hline$N A N O G$ & $\operatorname{miR} 5077-5 p$ & 773 & CDS & -100 & 94 & 19 \\
\hline PPARGCIA & $\operatorname{miR} 5144-5 p$ & 1450 & CDS & -104 & 94 & 21 \\
\hline FREM2 & $\operatorname{miR} 528-3 p$ & 1921 & CDS & -106 & 94 & 21 \\
\hline FXYD6 & $\operatorname{miR} 530-5 \mathrm{p}$ & 788 & CDS & -100 & 94 & 20 \\
\hline$L A M C 3$ & miR530-5p & 898 & CDS & -100 & 94 & 20 \\
\hline NDST1 & $\operatorname{miR} 530-5 p$ & 6055 & 3'UTR & -100 & 94 & 20 \\
\hline SLC35D1 & miR5339-5p & 795 & CDS & -102 & 96 & 21 \\
\hline EML1 & $\operatorname{miR} 535-3 p$ & 2092 & CDS & -106 & 94 & 21 \\
\hline LRP5 & $\operatorname{miR} 5488-5 p$ & 4185 & CDS & -102 & 94 & 21 \\
\hline SLC25A47 & $\operatorname{miR} 5510-5 \mathrm{p}$ & 678 & CDS & -108 & 94 & 21 \\
\hline PM20D2 & miR5514-5p & 1280 & CDS & -113 & 95 & 21 \\
\hline PPARA & $\operatorname{miR} 5515-3 p$ & 1497 & CDS & -106 & 94 & 21 \\
\hline ZSCAN22 & miR5526-3p & 2638 & 3'UTR & -102 & 94 & 21 \\
\hline$S H 3 B P 2$ & miR5532-3p & 8598 & 3'UTR & -104 & 94 & 22 \\
\hline NANOS1 & $\operatorname{miR} 5534 a-5 p$ & 1967 & 3'UTR & -106 & 96 & 21 \\
\hline$D U T$ & miR5543-5p & 1619 & 3'UTR & -93 & 94 & 21 \\
\hline OTUD4 & $\operatorname{miR} 5543-5 p$ & 3680 & 3'UTR & -93 & 94 & 21 \\
\hline COX 20 & miR5833-5p & 396 & CDS & -117 & 96 & 21 \\
\hline AKAPI1 & $\operatorname{miR} 827-3 p$ & 2985 & $\mathrm{CDS}$ & -100 & 94 & 21 \\
\hline
\end{tabular}

Table S1-S3 show information about the genes targeted by plant miRNAs that may be 122 involved in the development of various diseases. Most target genes are involved in the 123 development of cancer of various types: ENAH, MAPT, PRKCE, PRRT2, RBMS2, RHOBTB2, 124 RPS6KA5 and ZFHX3 - breast cancer (Aisina et al., 2019); ADAMTS5, PRAPRGG1A, PVR, 125 SPRY4 - colorectal cancer; CHSY1 - colorectal cancer and hepatocellular carcinoma; PPMIF, 126 FXYD6, DUT, FAM83H - hepatocellular carcinoma; HK2 - gallbladder cancer and leukaemia; C19orf6 - ovarian carcinoma; AFAP1 - oesophageal adenocarcinoma; IOGAP1 - pancreatic 
ductal adenocarcinoma; PPP2R5C - lung adenocarcinoma; PDAP1 - leukemia; AKAP11, OSTM1, LRP5 - osteopetrosis; WT1 - ovarian cancer and myeloid leukaemia; NRID2 - various cancers, including glioblastoma; CDC25B, DIRC2 - renal carcinoma; and UHRF1BP1 - cell carcinoma of the head and neck. Some genes are associated with other diseases: NR2F2 metabolic gene regulation and congenital heart defect; PRAPA, UFSPI - with increased cardiovascular disease; and ATP13A3 - pulmonary tumour arterial hypertension and psychiatric disorder. $B D N F$ has an important role in the neurogenesis and neuroplasticity of the brain; PSEN2 and LMNA are associated with Alzheimer's disease; ZNF442 has a role in psychiatric disorders; and NANOS1 is associated with retinoblastoma tumours. The list of oncological diseases caused by the target genes of the osa-miRNAs indicates that miRNAs can participate in the development of cancer not only in the gastrointestinal tract but also in other organs. Therefore, miRNAs that are ingested with food can be transferred to other tissues and organs.

The interaction of miRNAs and mRNA nucleotides of target genes shows how effectively these molecules bind. The schemes presented in Fig. 1 show the formation of hydrogen bonds between all the nucleotides of miR5075-3p, miR2866-5p, and miR2919 and the binding sites in mRNA. Because the MirTarget program takes into account the interaction of the noncanonical pairs $\mathrm{A}-\mathrm{C}$ and $\mathrm{G}-\mathrm{U}$, it can be seen that the interaction of miRNAs and mRNAs preserves the spiral structures of both molecules, and therefore, stacking interactions are found between all the nucleotides of the miRNA and mRNA, which stabilize the duplex. miRNA binding sites are located in the 5'UTR, CDS, and 3'UTR.

One form of evidence for the reliability of miRNA interaction with mRNA is the establishment of a conservative nucleotide sequence of binding sites in mRNA of target genes (Atambayeva et al., 2017; Bari, Orazova \& Ivashchenko, 2013; Bari et al., 2014; Yurikova et al., 2019). The results of the analysis of the similarity of the nucleotide sequences of the binding sites in mRNA of the target genes miR2102-5p, miR2919 and miR5075-3p are shown in Fig. 2. For all miR2102-5p, miR2919, and miR5075-3p binding sites, nucleotide conservation is present compared to the flanking nucleotides of mRNA target genes. With the complete complementarity of the nucleotides miRNA and mRNA $(\Delta \mathrm{G} / \Delta \mathrm{Gm}=100 \%)$ of the target genes, absolute conservatism of the site along the entire binding site should be observed, as previously shown (Atambayeva et al., 2017; Bari, Orazova \& Ivashchenko, 2013; Bari et al., 2014; Yurikova et al., 2019). When the $\Delta \mathrm{G} / \Delta \mathrm{Gm}$ value changes from $94 \%$ to $100 \%$ (Table 1), the basis for the interaction of the nucleotides miR2102-5p, miR2919 and miR5075-3p and mRNA are GC pairs.

\section{Characteristics of the interaction of osa-miRNA families with mRNAs of human genes}


162 The total number of osa-miRNAs of all families is 146, and the number of their target genes is 163 equal to 301 , which is $1.7 \%$ of 17,508 studied human genes. The characteristics of the interaction 164 of 93 osa-miRNAs of all family osa-miRNAs to 86 mRNAs of human genes with values from $16594 \%$ to $98 \%$ were established (Table 2). miRNA of families such as miR156b-3p, $166 \quad \operatorname{miR} 159 a .1, b, f-3 p, \quad \operatorname{miR} 164 a, b, c, d, f-5 p, \quad \operatorname{miR} 166 a, e-5 p, \quad \operatorname{miR} 166 b, c, d, h-5 p$, 167 miR167a,b,c,d,e,f,g,h,i,j-5p, miR172a,d-3p miR172c-3p, miR396d, miR396a,b-3p, miR531b$1685 \mathrm{p}, \mathrm{miR} 815 \mathrm{a}, \mathrm{b}, \mathrm{c}-3 \mathrm{p}, \mathrm{miR} 1428 \mathrm{~b}, \mathrm{c}, \mathrm{d}, \mathrm{e}-3 \mathrm{p}$ and miR1858a,b-5p, has one target gene per family. All 169 members of each miRNA family bind at one site due to the homology of their nucleotide 170 sequences. Therefore, the expression of the target gene for each miRNA family will depend on 171 the total concentration of all miRNA families. The miRNA families miR167e,i-3p, miR168b-5p, 172 miR1846a,b,c-5p and miR2907a,b,c,d-3p had two target genes. miR2907a,b,c,d-3p has target 173 genes IRAK2 and SLC25A37 with mRNAs of which these miRNAs interact with a large free 174 energy of $-123 \mathrm{~kJ} /$ mole and $-125 \mathrm{~kJ} /$ mole, respectively. miR444b.1,c.1-3p had three target genes 175 (C19orf57, KAZN, NRG1).

\begin{tabular}{|c|c|c|c|c|c|c|}
\hline Gene & osa-miRNA & $\begin{array}{c}\text { Start of } \\
\text { site, } n t\end{array}$ & $\begin{array}{c}\text { Region of } \\
\text { miRNA }\end{array}$ & $\begin{array}{c}\Delta \mathrm{G}, \\
\mathrm{kJ} / \mathrm{mole}\end{array}$ & $\begin{array}{c}\Delta \mathrm{G} / \Delta \mathrm{Gm}, \\
\%\end{array}$ & $\begin{array}{c}\text { Length, } \\
\text { nt }\end{array}$ \\
\hline ANKRD27 & miR1428b,c,d,e-3p & 244 & CDS & -98 & 96 & 21 \\
\hline$A P 2 A 2$ & miR156a,b,c,d,e,f,g,h,i,j,k-5p & 3797 & 3'UTR & -104 & 94 & 21 \\
\hline$O B F C 1$ & $\operatorname{miR} 156 a, b, c, d, e, f, g, h, i, j-5 p$ & 5427 & 3'UTR & -100 & 94 & 20 \\
\hline ZNF652 & $\operatorname{miR} 156 a, b, c, d, e, f, g, h, i, j-5 p$ & 8125 & 3'UTR & -100 & 94 & 20 \\
\hline $\mathrm{MROH} 2 \mathrm{~B}$ & $\operatorname{miR} 156 b-3 p$ & 4615 & CDS & -106 & 94 & 21 \\
\hline PKHDI & $\operatorname{miR} 159 a .1, b, f-3 p$ & 9966 & CDS & -108 & 98 & 21 \\
\hline$A S X L 1$ & $\operatorname{miR} 164 a, b, c, d, f-5 p$ & 1923 & CDS & -110 & 95 & 21 \\
\hline CHST11 & $\operatorname{miR} 166 a, e-5 p$ & 986 & CDS & -104 & 94 & 21 \\
\hline$C C N Y$ & $\operatorname{miR} 166 b, c, d, h-5 p$ & 367 & CDS & -110 & 95 & 21 \\
\hline PRICKLE2 & $\operatorname{miR} 167 a, b, c, d, e, f, g, h, i, j-5 p$ & 1959 & $\mathrm{CDS}$ & -106 & 94 & 21 \\
\hline$I L 17 R B$ & $\operatorname{miR} 167 e, i-3 p$ & 137 & CDS & -102 & 94 & 21 \\
\hline KIAA0528 & $\operatorname{miR} 167 e, i-3 p$ & 523 & CDS & -102 & 94 & 21 \\
\hline$A P O B R$ & $\operatorname{miR} 168 b-5 p$ & 55 & CDS & -110 & 95 & 21 \\
\hline$K L F 14$ & $\operatorname{miR} 168 b-5 p$ & 623 & $\mathrm{CDS}$ & -115 & 98 & 21 \\
\hline GPR31 & $\operatorname{miR} 172 a, d-3 p$ & 590 & CDS & -100 & 94 & 21 \\
\hline$A T P 12 A$ & $\operatorname{miR} 172 c-3 p$ & 3557 & 3'UTR & -102 & 94 & 21 \\
\hline EIF3B & $\operatorname{miR} 1846 a, b, c-5 p$ & 2194 & CDS & -119 & 97 & 21 \\
\hline FASN & $\operatorname{miR} 1846 a, b, c-5 p$ & 11 & 5'UTR & -117 & 95 & 21 \\
\hline C20orf 27 & $\operatorname{miR} 1858 a, b-5 p$ & 921 & 3'UTR & -115 & 95 & 21 \\
\hline$I R A K 2$ & $\operatorname{miR} 2907 a, b, d-3 p$ & 1488 & CDS & -123 & 94 & 22 \\
\hline$S L C 25 A 37$ & $\operatorname{miR} 2907 a, b, d-3 p$ & 884 & CDS & -125 & 95 & 22 \\
\hline EDN1 & $\operatorname{miR} 395 a-q, t, y-3 p$ & 1136 & 3'UTR & -108 & 96 & 21 \\
\hline$C D 22$ & $\operatorname{miR} 395 b, \mathrm{~d}, \mathrm{e}, \mathrm{g}, \mathrm{h}-\mathrm{t}, \mathrm{y}-3 \mathrm{p}$ & 2684 & 3'UTR & -104 & 94 & 21 \\
\hline CMKLRI & $\operatorname{miR} 396 a, b-3 p$ & 3970 & 3'UTR & -98 & 96 & 20 \\
\hline SCAMP5 & miR396a,b-5p & 1727 & 3'UTR & -102 & 94 & 21 \\
\hline SYVN1 & miR396a,b-5p & 854 & $\mathrm{CDS}$ & -102 & 94 & 21 \\
\hline AKAP13 & miR396d & 1736 & CDS & -100 & 94 & 20 \\
\hline RHBDF 1 & $\operatorname{miR} 444 a-3 p .1$, d.1-3p & 1071 & CDS & -108 & 94 & 21 \\
\hline RUNDCl & $\operatorname{miR} 444 a-3 p .1$, d.1-3p & 1191 & CDS & -108 & 94 & 21 \\
\hline CEP250 & $\operatorname{miR} 444 a-3 p .2$, b. 2, c. 2, d. $2, e-3 p$ & 1939 & CDS & -102 & 94 & 21 \\
\hline C19orf57 & $\operatorname{miR} 444 b .1, c .1-3 p$ & 714 & CDS & -106 & 94 & 21 \\
\hline$K A Z N$ & $\operatorname{miR} 444 b .1, c .1-3 p$ & 4874 & 3'UTR & -106 & 94 & 21 \\
\hline$N R G 1$ & $\operatorname{miR} 444 b .1, c .1-3 p$ & 2444 & 3'UTR & -106 & 94 & 21 \\
\hline
\end{tabular}


177

\begin{tabular}{lllllll}
\hline ATP6V0A4 & miR529a-3p & 241 & 5'UTR & -100 & 94 & 20 \\
CCDC94 & miR529a-3p & 379 & CDS & -100 & 94 & 20 \\
CHD2 & miR529a-3p & 6684 & 3'UTR & -100 & 94 & 20 \\
$M A P 7$ & miR529a-3p & 2137 & CDS & -100 & 94 & 20 \\
$M L L$ & miR529a-3p & 11418 & CDS & -100 & 94 & 20 \\
PDE4B & miR529a-3p & 2270 & CDS & -100 & 94 & 20 \\
ENAH & miR531b-5p & 106 & 5'UTR & -115 & 95 & 20 \\
TIFA & miR815a,b,c-3p & 186 & 5'UTR & -106 & 94 & 21 \\
\hline
\end{tabular}

The miRNAs of the large miR395-3p family had EDN1 and CD22 target genes, which are involved in the development of diabetes and in the control of immunity, respectively. If these miRNAs get in food in large quantities, then the probability of their impact on human health is high.

miR396a,b-3p can affect the expression of the CMKLR1 gene, which is involved in cardiovascular disease, and for miR396a,b-5p, the SCAMP5 and SYVN1 genes are targeted, the expression of which changes with autism and colon cancer, respectively. miRNAs of the miR444-3p family have binding sites in the mRNA of six genes (Table S4). Their target genes RHBDF1, RUNDC1, CEP250, C19orf57, KAZN, and NRG1 are involved in oncogenesis and other diseases.

Therefore, ingestion of these miRNAs with food in humans can significantly affect metabolic processes. miR529a-3p had binding sites in the mRNA of six genes that are involved in the regulation of several physiological processes (Table S5). If a person in the process of evolution consumed this miRNA as a necessary regulator of the expression of its target genes, then for this miRNA there must be target genes.

Fig. 3 shows the interaction patterns of the nucleotide sequences of some representatives of the miRNA families with the mRNA of their target genes. These data indicate a good predictive power for identifying miRNA associations and target genes. The visibility of the interaction of miRNA and mRNA nucleotides in combination with the quantitative characteristics of binding miRNA and mRNA allows us to consider these associations stable and real.

Note that the nucleotide sequences miR156, miR166, miR395, miR396, and miR444 did not have homologous miRNAs among 2565 human miRNAs from the miRBase base. Therefore, these miRNAs do not directly have common binding sites for human miRNAs and can independently regulate the expression of their target genes.

To confirm the conservatism of the interaction of pl-miR with human target genes, we plotted the web logo for mRNA sections containing pl-miR binding sites (Fig. 2). The graphs show the high conservatism of these binding sites compared to flanking nucleotide sequences. The miR156a-j-5 family, consisting of 10 miRNAs, was associated with the mRNA of seven genes (Table S4). The miR156a-j-5 binding sites in each of the genes differed in the number of hydrogen bonds (Fig. 3) and the value of the free interaction energy. Similar results were 
obtained for other miRNA families: miR164e-5p, miR168b-5p, miR396c-3p, miR444a-3p.1,d.13p, miR529a-3p, miR815a,b,c-3p, miR1846a,b,c-5p, miR1858a,b-5p, miR21181-3p, miR2275d-

$2103 p$, miR2907a,b,d-3p, and miR395a-y-3p (Fig. 2). The conservatism of such bonds between

211 miRNAs and their target genes was established by us for many associations of miRNAs and their

212 target genes in animals and plants (Atambayeva et al., 2017; Bari, Orazova \& Ivashchenko,

213 2013; Bari et al., 2014; Yurikova et al., 2019). These bonds have persisted over tens of millions

214 of years of evolution and indicate the early emergence of the process of regulation by miRNA

215 molecules of target gene expression in animals and plants.

\section{Discussion}

217 Based on the results obtained in this work, the fact of the interaction of pl-miRs with mRNA of 218 human genes is beyond question. It is necessary to establish the possibilities for these miRNAs 219 to enter the human and animal organisms. Several studies have shown that miRNAs in various 220 parts of plants are present in exosomes 30-400 $\mathrm{nm}$ in size and are distributed in the body as part 221 of these nanoparticles (Bang \& Thum, 2012; Denzer et al., 2000; Xiao et al., 2018). Such compaction of miRNAs in exosomes contributes to their conservation and facilitates the entry of miRNAs into animals through the digestive tract (Redis et al., 2012; Théry, Zitvogel \& Amigorena, 2002; Valadi et al., 2007). Further exosomes together with endogenous exosomes with blood move to many tissues and organs. According to the physicochemical properties, plant miRNAs do not differ from animal miRNAs, which makes them competitive when interacting with mRNA target genes. There are no known limitations for the above-described process of ingestion of plant-miRNAs into humans and animals.

Basically, not all pl-miRs will have human target genes, but the most common and vital plmiRs present in plants can have target genes in animals and humans for a long time eating them. Such pl-miRs usually participate in maintaining the basic physiological functions of plants (productivity, resistance to biotic and abiotic stresses, growth and development). For example, developed rice lines overexpressing MIR529a have been shown to have increased resistance to oxidative stress (Chen \& Li, 2018; Cimini et al., 2019). The participation of osa-miR159f, osamiR1871, osa-miR398b, osa-miR408-3p, osa-miR2878-5p, osa-miR528-5p and osa-miR397a in the regulation of a number of physiological processes of rice has been established (Balyan et al., 2017). The expression of miRNA of Setaria italica (sit) changed many times: sit-miR1432-3p, sit-miR156a-5p, sit-miR156b-5p, sit-miR164a-5p, sit-miR167b-5p, sit-miR171c-3p, sit miR2118-3p, sit-miR390-5p, sit-miR394-5p, sit-miR395-3p, sit-miR408-3p, sit-miR529a-3p, sitmiR529b-3p, and sit-miR827, sit-miR159b-3p, sit-miR319c-5p, sit-miR528-5p and sit-miR535-

$2415 p$ under various stresses (Wang et al., 2016). In a broader evolutionary context, miRNAs of 242 Morus notabilis were compared to those of seven other plants, including five dicotyledons, 
243

244

245

246

247

248

249

250

251

252

253

254

255

256

257

258

259

260

261

262

263

264

265

266

267

268

269

270

271

272

273

274

275

276

277

Arabidopsis thaliana, Glycine max, Malus domestica, Populus trichocarpa, Ricinus communis, and two monocotyledons, Oryza sativa and Zea mays. Of the 31 Morus notabilis miRNA families, 24 were conserved in the seven plant species. These miRNAs were classified into wellconserved miRNA families. Prominent among them were mulberry miR160b, miR164a, miR167a, miR169a, miR390, and miR396b, which completely matched their counterparties in the seven other plant species, suggesting that those miRNAs were extremely conserved, and might play critical physiological roles in both dicotyledons and monocotyledons. However, seven miRNA families, miR482, miR529, miR858, miR4376, miR4414, miR4995, and miR5523, were found in only one or two plant species. The present data indicated that the conserved miRNA families (miR156, miR166, miR167, miR168, and miR535) miR159, miR160, miR164, miR169, miR171, miR172, miR390, miR396, miR397, miR529 and miR4376, miR162, miR393, miR395, miR398, miR399, miR408 and miR4414 miR319, miR482, miR827, miR828, miR858, miR2111, miR4995 and miR5523 were expressed across a vast range exceeded in all three tissues (Jia et al., 2014). In African rice Oryza glaberrima (ogl), some miRNAs such as ogl-miR1561, ogl-miR166c, ogl-miR166k, ogl-miR168a, ogl-miR167i, oglmiR171f, ogl-miR1846d of the control library and ogl-miR408, ogl-miR528, ogl-miR156, oglmiR390, and ogl-miR396c of the treated library had higher reads than their complementary strand. This is because miRNA-3p and miRNA-5p may function simultaneously to regulate gene expression (Mondal et al., 2018). It must be understood that the expression of the target gene under the influence of miRNAs can increase with decreasing miRNA concentration below the average physiological level or decrease with increasing miRNA concentration. The data on changes in miRNA concentration in different plants show that the amount of miRNA consumed with food depends on the stage of plant ontogenesis, growing conditions, plant organs, food processing, etc. (Liu et al., 2017). The concentration of pl-miRs after various processing of raw products decreases, but the remaining miR enter the body (Luo et al., 2017; Zhang et al., 2012; Zhou et al., 2015).

\section{Conclusions}

As a result of our study, for the first time, among 17508 human genes, 942 target genes for 277 osa-miRNAs were established. The identified target genes account for $5.4 \%$ of the total number of studied human genes. miRNA binding sites were found in the CDS, 5'UTR and 3'UTR. The largest number of genes were targeted by osa-miR2102-5p, osa-miR5075-3p, osa-miR2097-5p, and osa-miR2919, which can bind to the mRNA of 38, 36, 23, and 19 genes, respectively. Since osa-miRNAs ingested through plant food have many target genes, they should be controlled in the human body. Most osa-miRNA target genes are involved in the development of diseases, which makes it easier to clarify the role of miRNAs in these processes. Many osa-miRNA target 
genes contribute to the development of breast cancer, and other cancer types. The other target genes are involved in cardiovascular and neurodegenerative diseases. Some osa-miRNAs can be effective regulators of human gene expression. The effect of miRNAs can be both positive, contributing to the cure of diseases, and negative, causing a wide range of diseases.

\section{Materials \& Methods}

The nucleotide sequences of the mRNAs of 17508 targeted genes were downloaded from NCBI

GenBank (http://www.ncbi.nlm.nih.gov). The nucleotide sequences of the miRNAs were taken from miRBase v.22 (http://www.mirbase.org/). The miRNA binding sites in the mRNAs of several genes were predicted using the MirTarget program (Ivashchenko et al., 2016). This program defines the following features of miRNA binding to mRNA: a) the start of the initiation of the miRNA binding to the mRNAs from the first nucleotide of the mRNA's; b) the localization of the miRNA binding sites in the 5'-untranslated region (5'UTR), coding domain sequence (CDS) and 3'-untranslated region (3'UTR) of the mRNAs; c) the free energy of the interaction between miRNA and the mRNA $(\Delta \mathrm{G}, \mathrm{kJ} / \mathrm{mole})$; and $\mathrm{d})$ the schemes of nucleotide interactions between miRNAs and mRNAs. The ratio $\Delta \mathrm{G} / \Delta \mathrm{Gm}(\%)$ is determined for each site ( $\Delta \mathrm{Gm}$ equals the free energy of the miRNA binding with its fully complementary nucleotide sequence). The MirTarget program finds hydrogen bonds between adenine (A) and uracil (U), guanine $(\mathrm{G})$ and cytosine $(\mathrm{C})$, and $\mathrm{G}$ and $\mathrm{U}, \mathrm{A}$ and $\mathrm{C}$. The distances between the bound $\mathrm{A}$ and $\mathrm{C}$ $(1.04 \mathrm{~nm})$ and $\mathrm{G}$ and $\mathrm{U}(1.02 \mathrm{~nm})$ are similar to those between bound $\mathrm{G}$ and $\mathrm{C}$ and $\mathrm{A}$ and $\mathrm{U}$, which are equal to $1.03 \mathrm{~nm}$ (Garg \& Heinemann, 2018; Kool, 2001; Leontis, Stombaugh \& Westhof, 2002). The numbers of hydrogen bonds in the G-C, A-U, G-U and A-C interactions were 3, 2, 1 and 1, respectively. By comparison, MirTarget differs from other programs in terms of finding the binding sites of miRNA on the mRNAs of plant genes (Dai, Zhuang \& Zhao, 2011) in that 1) it takes into account the interaction of the miRNA with mRNA over the entire miRNA sequence; 2) takes into account noncanonical pairs G-U and A-C; and 3) calculates the free energy of the interaction of the miRNA with mRNA, and when two or more miRNAs are bound with one mRNA or, if the binding sites of two different miRNAs coincide in part, the preferred miRNA binding site is considered to be the one for which the free binding energy, $\Delta \mathrm{G}$, is greater. The MirTarget program does not work directly with the miRBase and NCBI databases. The search for target genes from 17,508 human genes in a special format from NCBI for the known miRNAs from miRBase will be available on request at mirtarget8@ gmail.com.

Supplemental table 1. osa-miRNA list of 1-4 human target genes. 
Supplemental table 5. osa-miRNA families of target human genes involved in biological processes.

\section{Funding}

316 The work was carried out with the financial support of the Ministry of Education and Science of

317 the Republic of Kazakhstan within the framework of the grant №AP05132460.

\section{AUTHOR CONTRIBUTIONS}

A.I., A.R performed the research and analyzed the data. A.P., D.A contributed analytic tools and

321 methods. A.I., A.R., A.P., D.A wrote the article.

322

\section{References}

Aisina D, Niyazova R, Atambayeva S, Ivashchenko A. 2019. Prediction of clusters of miRNA binding sites in mRNA candidate genes of breast cancer subtypes. PeerJ 7: e8049 DOI 10.7717/peerj.8049.

Arroyo JD, Chevillet JR, Kroh EM, Ruf IK, Pritchard CC, Gibson DF, Mitchell PS, in human plasma. Proceedings of the National Academy of Sciences of the United States of America 108: 5003-5008 DOI 10.1073/pnas.1019055108.

Arteaga-Vazquez M, Caballero-Perez J, Vielle-Calzada JP. 2006. A family of microRNAs present in plants and animals. Plant Cell 18: 3355-3369 DOI 10.1105/tpc.106.044420. BMC Genomics 18: 428. DOI 10.1186/s12864-017-3811-6.

Axtell MJ, Westholm JO, Lai EC. 2011. Vive la difference: biogenesis and evolution of microRNAs in plants and animals. Genome Biology 12: 1-13. DOI 10.1186/gb-2011-12-4221.

Balyan S, Kumar M, Mutum R, Raghuvanshi U, Agarwal P, Mathur S, Raghuvanshi S. 2017. Identification of miRNA-mediated drought responsive multi-tiered regulatory network in drought tolerant rice, Nagina 22. Scientific Reports 7: 15446 DOI 10.1038/s41598-01715450-1.

Bang C, Thum T. 2012. Exosomes: new players in cell-cell communication. The International Journal of Biochemistry \& Cell Biology 44:2060-2064 DOI 10.1016/j.biocel.2012.08.007.

Bari A, Orazova S, Ivashchenko A. 2013. miR156- and miR171-binding sites in the proteincoding sequences of several plant genes. BioMed Research International 2013: 1-7 DOI $10.1155 / 2013 / 307145$. 
Bari A, Sagaidak I, Pinskii I, Orazova S, Ivashchenko A. 2014. Binding of miR396 to mRNA of Genes Encoding Growth-Regulating Transcription Factors of Plants. Russian Journal of Plant Physiology 61: 807-810 DOI 10.1134/S1021443714050033.

Buck AH, Coakley G, Simbari F, McSorley HJ, Quintana JF, Le Bihan T, Kumar

A, Maizels RM. 2014. Exosomes secreted by nematode parasites transfer small RNAs to mammalian cells and modulate innate immunity. Nature Communications 5: 5488 DOI $10.1038 /$ ncomms6488.

Chen J, Li L. 2018. Multiple Regression Analysis Reveals MicroRNA Regulatory Networks in Oryza sativa under Drought Stress. International Journal of Genomics 2018: 1-12 DOI 10.1155/2018/9395261.

Chiang K, Shu J, Zempleni J, Cui J. 2015. Dietary MicroRNA Database (DMD): An Archive 10.1371/journal.pone.0128089.

Chin AR, Fong MY, Somlo G. 2016. Cross-kingdom inhibition of breast cancer growth by plant miR159. Cell Research 26: 217-228 DOI 10.1038/cr.2016.13.

Cimini S, Gualtieri C, Macovei A, Balestrazzi A. De Gara L, Locato V. 2019. Redox Balance-DDR-miRNA Triangle: Relevance in Genome Stability and Stress Responses in Plants. Frontiers in Plant Science 10: 989 DOI 10.3389/fpls.2019.00989.

Cong L, Zhao Y, Pogue AI, Lukiw WJ. 2018. Role of microRNA (miRNA) and Viroids in Lethal Diseases of Plants and Animals. Potential Contribution to Human Neurodegenerative Disorders. Biochemistry (Moscow) 83: 1018-1029 DOI 10.1134/S0006297918090031.

Cui J, Zhou B, Ross SA, Zempleni J. 2017. Nutrition, microRNAs, and Human Health. Advances in Nutrition 8: 105-112 DOI 10.3945/an.116.013839.

Dai X, Zhuang Z, Zhao P. 2011. Computational Analysis of miRNA Targets in Plants: Current Status and Challenges. Briefings in Bioinformatics 12: 115-121 DOI 10.1093/bib/bbq065. dendritic cells carry MHC Class II-expressing microvesicles at their surface. Journal of Immunology 165:1259-1265 DOI 10.4049/jimmunol.165.3.1259.

Escrevente C, Keller S, Altevogt P, Costa J. 2011. Interaction and uptake of exosomes by ovarian cancer cells. BMC Cancer 11: 108 DOI 10.1186/1471-2407-11-108.

Garg A, Heinemann U. 2018. A novel form of RNA double helix based on G.U and C. $\mathrm{A}^{+}$wobble base pairing. RNA 24: 209-218 DOI 10.1261/rna.064048.117. 
Hou D, He F, Ma L, Cao M, Zhou Z, Wei Z, Xue Y, Sang X, Chong H, Tian C, Zheng S, Li J, Zen K, Chen X, Hong Z, Zhang CY, Jiang X. 2018. The potential atheroprotective role of plant MIR156a as a repressor of monocyte recruitment on inflamed human endothelial cells. The Journal of Nutritional Biochemistry 57: 197-205 DOI 10.1016/j.jnutbio.2018.03.026.

Hoy AM, Buck AH. 2012. Extracellular small RNAs: what, where, why? Biochemical Society Transactions 40: 886-890 DOI 10.1042/BST20120019.

Ivashchenko AT, Pyrkova AY, Niyazova RY, Alybayeva A, Baskakov K. 2016. Prediction of miRNA binding sites in mRNA. Bioinformation 12: 237-240. DOI $10.6026 / 97320630012237$.

Javed M, Solanki M, Sinha A, Shukla LI. 2017. Position Based Nucleotide Analysis of miR168 Family in Higher Plants and its Targets in Mammalian Transcripts. Microrna 6: 136142 DOI 10.2174/2211536606666170215154151.

Jia L, Zhang D, Qi X, Ma B, Xiang Zh, He N, Zhang J. 2014. Identification of the Conserved and Novel miRNAs in Mulberry by High-Throughput Sequencing. PLOS One 9: 8 DOI 10.1371/journal.pone.0104409.

Jonathan WS, Andrew EH, Stephanie KI, Aaron LB, Stephen YC. 2013. Ineffective delivery of diet-derived microRNAs to recipient animal organisms. RNA Biology 10: 1107-1116 DOI 10.4161/rna.24909.

Jones Buie JN, Goodwin AJ, Cook JA, Halushka PV, Fan H. 2016. The role of miRNAs in cardiovascular disease risk factors. Atherosclerosis 254: 271-281 DOI 10.1016/j.atherosclerosis.2016.09.067.

Kool ET. 2001. Hydrogen bonding, base stacking, and steric effects in DNA replication. Annual Review of Biophysics and Biomolecular Structure 30: 1-22 DOI 10.1146/annurev.biophys.30.1.1.

Lang C, Karunairetnam S, Lo KR, Kralicek AV, Crowhurst RN, Gleave AP, MacDiarmid RM, Ingram JR. 2019. Common Variants of the Plant microRNA-168a Exhibit Differing Silencing Efficacy for Human Low-Density Lipoprotein Receptor Adaptor Protein 1 (LDLRAP1). Microrna 8: 166-170 DOI 10.2174/2211536608666181203103233.

Leontis NB, Stombaugh J, Westhof E. 2002. The non-Watson-Crick base pairs and their associated isostericity matrices. Nucleic Acids Research 30: 3497-3531 DOI 10.1093/nar/gkf481.

Liang H, Huang L, Cao J, Zen K, Chen X, Zhang CY. 2012. Regulation of mammalian gene expression by exogenous microRNAs. Wiley Interdisciplinary Reviews-RNA 3: 733-742 DOI 10.1002/wrna.1127. 
Liang H, Zen K, Zhang J, Zhang CY, Chen X. 2013. New roles for microRNAs in crossspecies communication. RNA Biology 10: 367-370 DOI 10.4161/rna.23663.

Liang H, Zhang S, Fu Z, Wang Y, Wang N, Liu Y, Zhao C, Wu J, Hu Y, Zhang J, Chen X, Zen K, Zhang CY. 2015. Effective detection and quantification of dietetically absorbed plant microRNAs in human plasma. The Journal of Nutritional Biochemistry 26: 505-512 DOI 10.1016/j.jnutbio.2014.12.002.

Liu W, Meng J, Cui J, Luan Yu. 2017. Characterization and Function of MicroRNAs in Plants. Frontiers in Plant Science 8. DOI 10.3389/fpls.2017.02200.

Lukasik A, Zielenkiewicz P. 2016. Plant microRNAs - novel players in natural medicine? The International Journal of Molecular Sciences 18: 1-16 DOI 10.3390/ijms18010009.

Luo Y, Wang P, Wang X, Wang Y, Mu Z, Li Q, Fu Y, Xiao J, Li G, Ma Y, Gu Y, Jin L, Ma J, Tang Q, Jiang A, Li X, Li M. 2017. Detection of dietetically absorbed maize-derived microRNAs in pigs. Scientific Reports 7: 1-10 DOI 10.1038/s41598-017-00488-y.

Makarova JA, Shkurnikov MU, Wicklein D, Lange T, Samatov TR, Turchinovich AA, Tonevitsky AG. 2016. Intracellular and extracellular microRNA: an update on localization and biological role. Progress in Histochemistry and Cytochemistry 51: 33-49 DOI 10.1016/j.proghi.2016.06.001.

Malloci M, Perdomo L, Veerasamy M, Andriantsitohaina R, Simard G, Martinez MC. 2018. Extracellular vesicles: mechanisms in human health and disease. Antioxidants \& Redox Signaling 30: 813-856 DOI 10.1089/ars.2017.7265.

Melnik BC, John SM, Schmitz G. 2014. Milk: an exosomal microRNA transmitter promoting thymic regulatory $\mathrm{T}$ cell maturation preventing the development of atopy? The Journal of Translational Medicine 12: 1-11 DOI 10.1186/1479-5876-12-43.

Millar AA, Waterhouse PM. 2005. Plant and animal microRNAs: similarities and differences. Functional \& Integrative Genomics 5: 129-135 DOI 10.1007/s10142-005-0145-2.

Mondal T, Panda A, Rawal H, Sharma T. 2018. Discovery of microRNA-target modules of African rice (Oryza glaberrima) under salinity stress. Scientific Reports 8: 570 DOI 10.1038/s41598-017-18206-z.

Montecalvo A, Larregina AT, Shufesky WJ, Stolz DB, Sullivan ML, Karlsson JM, Baty CJ, Gibson GA, Erdos G, Wang Z, Milosevic J, Tkacheva OA, Divito SJ, Jordan R, Lyons-Weiler J, Watkins SC, Morelli AE. 2012. Mechanism of transfer of functional microRNAs between mouse dendritic cells via exosomes. Blood 119: 756-766 DOI 10.1182/blood-2011-02-338004.

Moran Y, Agron M, Praher D, Technau U. 2017. The evolutionary origin of plant and animal microRNAs. Nature Ecology \& Evolution 1: 1-22 DOI 10.1038/s41559-016-0027. 
Nair SK, Wang N, Turuspekov Y, Pourkheirandish M, Sinsuwongwat S, Chen G, Sameri M, Tagiri A, Honda I, Watanabe Y, Kanamori H, wicker T, Stein N, Nagamura Y, Matsumoto T, Komatsuda T. 2010. Cleistogamous flowering in barley arises from the suppression of microRNA-guided HvAP2 mRNA cleavage. Proceedings of the National Academy of Sciences of the United States of America 107: 490-495 DOI 10.1073/pnas.0909097107.

Perge P, Nagy Z, Decmann A, Igaz I, Igaz P. 2017. Potential relevance of microRNAs in interspecies epigenetic communication, and implications for disease pathogenesis. RNA Biology. 14: 391-401 DOI 10.1080/15476286.2016.1251001.

Pirro S, Minutolo A, Galgani A, Potesta M, Colizzi V, Montesano C. 2016. Bioinformatics prediction and experimental validation of microRNAs involved in cross-kingdom interaction. The Journal of Computational Biology 23: 976-989 DOI 10.1089/cmb.2016.0059.

Pogue AI, Clement C, Hill JM, Lukiw WJ. 2014. Evolution of microRNA (miRNA) structure and function in plants and animals: relevance to aging and disease. Journal of Aging Science 2: 1-12 DOI 10.4172/2329-8847.1000119.

Redis RS, Calin S, Yang Y, You MJ, Calin GA. 2012. Cell-to-cell miRNA transfer: from body homeostasis to therapy. Pharmacology \& Therapeutics 136:169-174 DOI 10.1016/j.pharmthera.2012.08.003.

Rutter BD, Innes RW. 2018. Extracellular vesicles as key mediators of plant-microbe interactions. Current Opinion in Plant Biology 44: 16-22 DOI 10.1016/j.pbi.2018.01.008.

Stephen Y, Snow J. 2017. Formidable challenges to the notion of biologically important roles for dietary small RNAs in ingesting mammals. Genes and Nutrition 12: 13 DOI 10.1186/s12263-017-0561-7.

Thery C, Zitvogel L, Amigorena S. 2002. Exosomes: composition, biogenesis and function. Nature Reviews Immunology 2:569-579 DOI 10.1038/nri855.

Valadi H, Ekström K, Bossios A, Sjöstrand M, Lee JJ, Lötvall JO. 2007. Exosomemediated transfer of mRNAs and microRNAs is a novel mechanism of genetic exchange between cells. Nature Cell Biology 9:654-659 DOI 10.1038/ncb1596.

van der Grein SG, Nolte-'t Hoen EN. 2014. "Small Talk" in the Innate Immune System via RNA-Containing Extracellular Vesicles. Frontiers in Immunology 5: 542 DOI 10.3389/fimmu.2014.00542.

Vaucheret H, Chupeau Y. 2012. Ingested plant miRNAs regulate gene expression in animals. Cell Research 1: 3-5 DOI 10.1038/cr.2011.164.

Wagner AE, Piegholdt S, Ferraro M, Pallauf K, Rimbach G. 2015. Food derived microRNAs. Food \& Function 6: 714-718 DOI 10.1039/c4fo01119h. 
Wang Yo, Li L, Tang Sh, Liu J, Zhang H, Zhi H, Jia G, Diao X. 2016. Combined small RNA and degradome sequencing to identify miRNAs and their targets in response to drought in foxtail millet. BMC Genomics 17: 57 DOI 10.1186/s12863-016-0364-7.

\section{Xiao J, Feng S, Wang X, Long K, Luo Y, Wang Y, Ma J, Tang Q, Jin L, Li X, Li M. 2018.} Identification of exosome-like nanoparticle-derived microRNAs from 11 edible fruits and vegetables. PeerJ 6: e5186 DOI 10.7717/peerj.5186.

Xie W, Weng A, Melzig MF. 2016. MicroRNAs as new bioactive components in medicinal plants. Planta Medica 82: 1153-1162. DOI 10.1055/s-0042-108450.

Yurikova OY, Aisina DE, Niyazova RE, Atambayeva SA, Labeit S, Ivashchenko AT. 2019. The Interaction of miRNA-5p and miRNA-3p with the mRNAs of Orthologous Genes. Mol Biol (Mosk) 53: 692-704 DOI 10.1134/S0026898419040189.

Zempleni J, Aguilar-Lozano A, Sadri M, Sukreet S, Manca S, Wu D, Zhou F, Mutai E. 2017. Biological Activities of Extracellular Vesicles and Their Cargos from Bovine and Human Milk in Humans and Implications for Infants. The Journal of Nutrition 147: 3-10 DOI 10.3945/jn.116.238949.

Zhang L, Chen T, Yin Yo, Zhang Ch, Zhang Yo. 2019. Dietary microRNA-A Novel Functional Component of Food. Advances in Nutrition 10: 711-721. DOI 10.1093/advances/nmy127.

Zhang L, Hou D, Chen X, Li D, Zhu L, Zhang Y, Li J, Bian Z, Liang X, Cai X, Yin Y, Wang C, Zhang T, Zhu D, Zhang D, Xu J, Chen Q, Ba Y, Liu J, Wang Q, Chen J, Wang J, Wang M, Zhang Q, Zhang J, Zen K, Zhang CY. 2012. Exogenous plant MIR168a specifically targets mammalian LDLRAP1: evidence of cross-kingdom regulation by microRNA. Cell Research 22: 107-126 DOI 10.1038/cr.2011.158.

Zhang H, Li Y, Liu Y, Liu H, Wang H, Jin W, Zhang Y, Zhang C, Xu D. 2016. Role of plant microRNA in cross-species regulatory networks of humans. BMC Systems Biology 10: 1-10 DOI 10.1186/s12918-016-0292-1.

Zhao Q, Liu Yu, Zhang N, Hu M, Zhang H, Joshi T, Xu D. 2018. Evidence for plant-derived xenomiRs based on a large-scale analysis of public small RNA sequencing data from human samples. PLOS One 13: 6 DOi 10.1371/journal.pone.0187519.

ZhaoY, Cong L, Lukiw WJ. 2018. Plant and animal microRNAs (miRNAs) and their potential for interkingdom communication. Cellular and Molecular Neurobiology 38: 133-140 DOI 10.1007/s10571-017-0547-4.

Zhou Z, Li X, Liu J, Dong L, Chen Q, Liu J, Kong H, Zhang Q, Qi X, Hou D, Zhang L, Zhang G, Liu Y, Zhang Y, Li J, Wang J, Chen X, Wang H, Zhang J, Chen H, Zen 
K, Zhang CY. 2015. Honeysuckle-encoded atypical microRNA2911 directly targets

524 influenza A viruses. Cell research 1: 39-49 DOI 10.1038/cr.2014.130. 


\begin{tabular}{|c|c|}
\hline Gene, miRNA, srart of site, region, $\Delta \mathrm{G}, \Delta \mathrm{G} / \Delta \mathrm{Gm}$ & Gene, miRNA, srart of site, region, $\Delta \mathrm{G}, \Delta \mathrm{G} / \Delta \mathrm{Gm}$ \\
\hline RPS6KA5, miR5075-3p, 261, CDS, -121, 98, 21 & ZNF442, miR2866-5p, $1020, \mathrm{CDS},-98,96,20$ \\
\hline 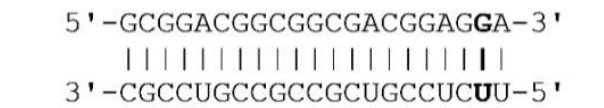 & 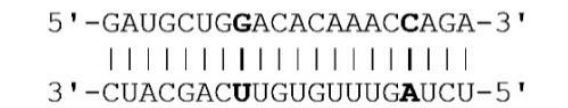 \\
\hline ZNHIT2, miR2925-5p, 559, CDS, -106, 94, 19 & C14orf142, miR414-5p, 281, CDS, -104, 94, 21 \\
\hline 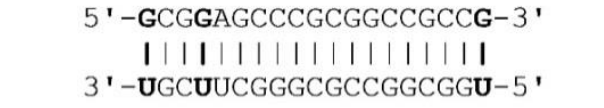 & 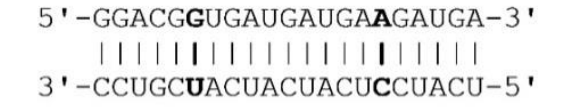 \\
\hline$E M L 1$, miR535-3p, 2092, CDS, -106, 94, 21 & C1D, miR2919, 543, 3'UTR, -102, 94, 19 \\
\hline 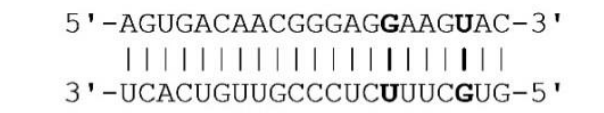 & 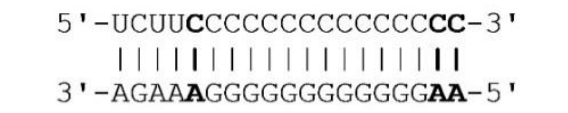 \\
\hline
\end{tabular}

Figure 1. Schemes of the interaction of the nucleotide sequences of osa-miRNA with mRNA human genes. 


\begin{tabular}{|c|c|}
\hline osa-miRNA & Logo plots \\
\hline $\operatorname{miR2102-5p}$ & 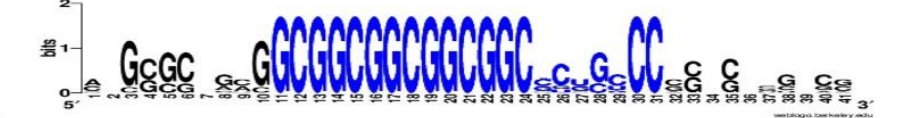 \\
\hline $\operatorname{miR2919}$ & 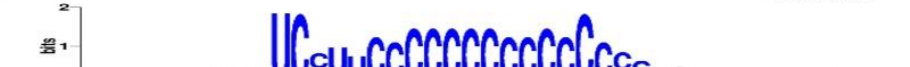 \\
\hline miR5075-3p & Gen \\
\hline $\operatorname{miR156a,b,c,d,e,f,g,h,I,j-5p}$ & 管- \\
\hline $\operatorname{miR} 164 e-5 p$ & 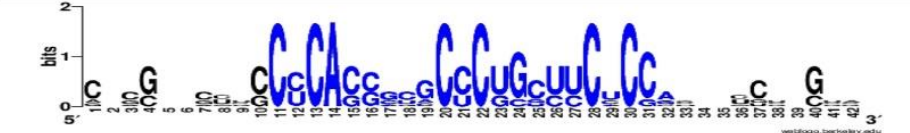 \\
\hline $\operatorname{miR} 168 b-5 p$ & 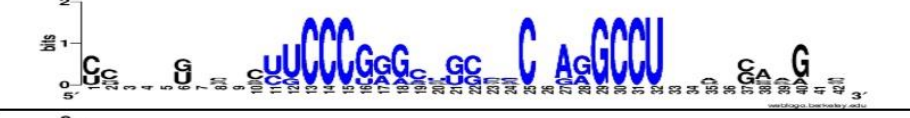 \\
\hline $\operatorname{miR395a,b,d,e,g,h,I,j,k,l,m,n,p,q,r,s,y-3p}$ & 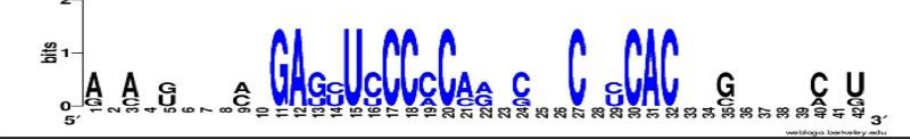 \\
\hline $\operatorname{miR396c-3p}$ & 帝-1 \\
\hline miR444a-3p.1,d.1-3p & \\
\hline $\operatorname{miR} 529 a-3 p$ & 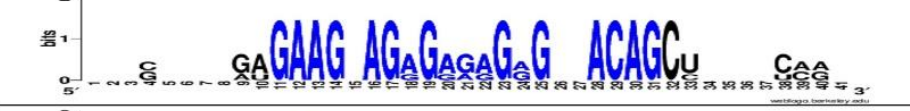 \\
\hline $\operatorname{miR815a,b,c-3p}$ & 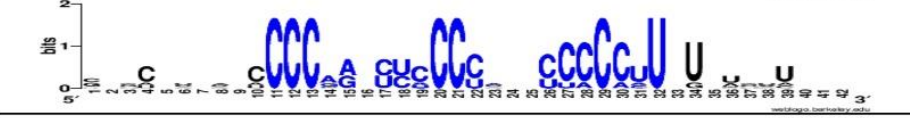 \\
\hline $\operatorname{miR1846a,b,c-5p}$ & $\hat{C}_{\mathrm{G}} \mathrm{GC}_{\mathrm{Gu}}$ \\
\hline miR1858a,b-5p & $\begin{array}{ll}2 \\
2\end{array}$ \\
\hline $\operatorname{miR21181-3p}$ & 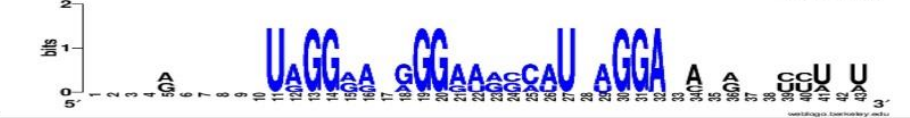 \\
\hline miR2275d-3p & 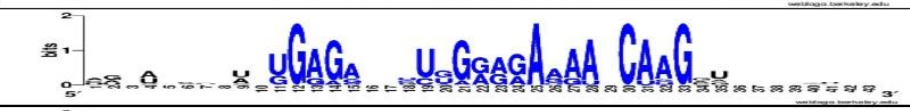 \\
\hline $\operatorname{miR2907a,b,d-3p}$ & 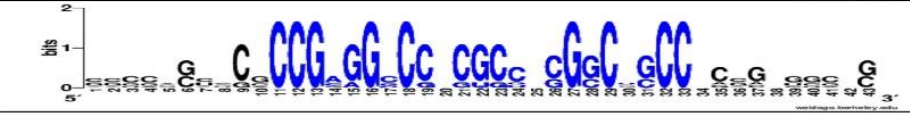 \\
\hline
\end{tabular}

Figure 2. Logo plots of the nucleotide sequence variability of mRNA regions of human genes containing the binding sites of osa-miRNA. 
bioRxiv preprint doi: https://doi.org/10.1101/2020.01.02.893040; this version posted January 2, 2020. The copyright holder for this preprint (which was not certified by peer review) is the author/funder, who has granted bioRxiv a license to display the preprint in perpetuity. It is made available under aCC-BY-NC-ND 4.0 International license.

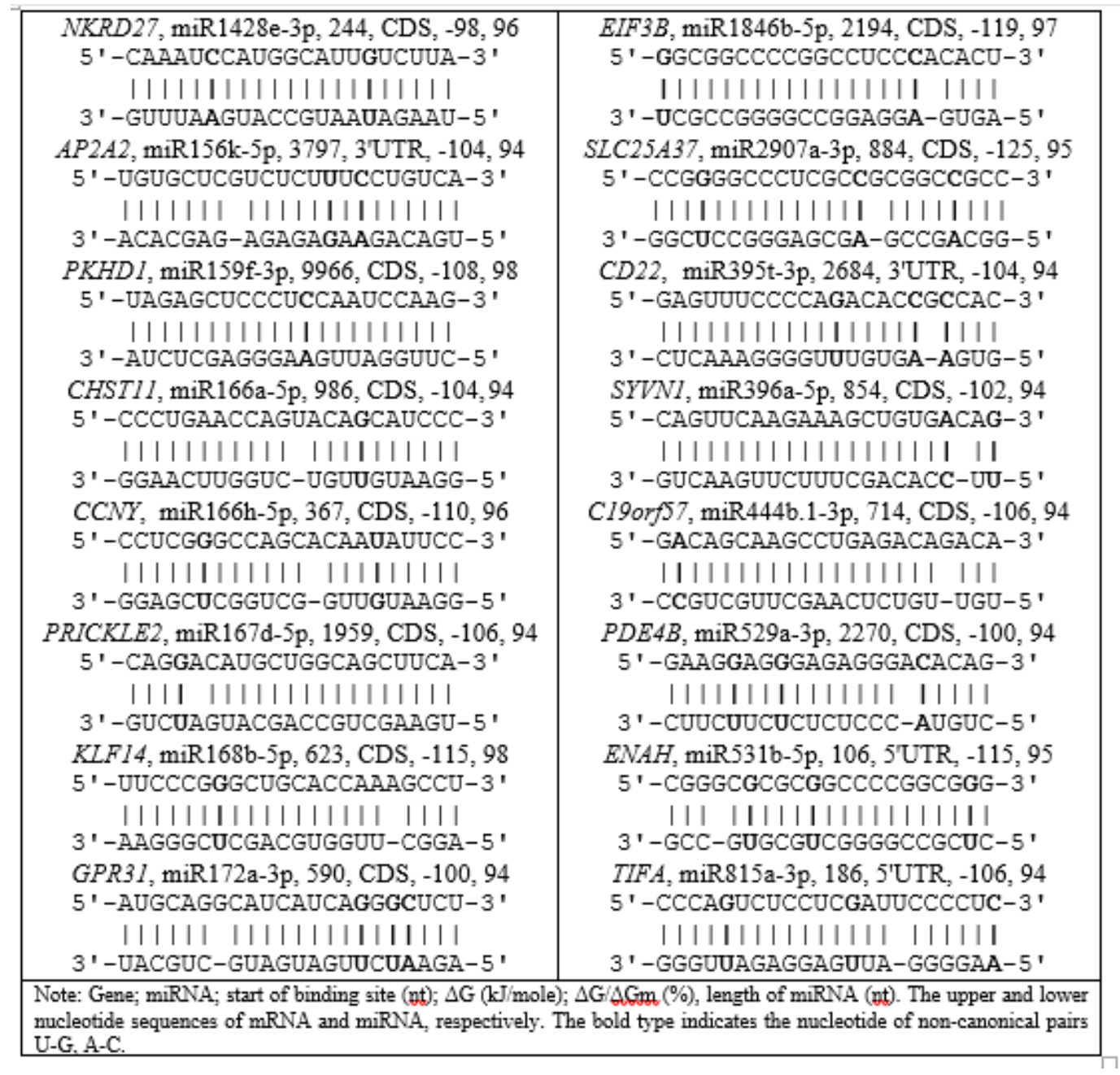

Figure 3. Schemes of the interaction of nucleotide sequences of osa-miRNA families with mRNA human genes. 


\section{Parsed Citations}

Aisina D, Niyazova R, Atambayeva S, Ivashchenko A 2019. Prediction of clusters of miRNA binding sites in mRNA candidate genes of breast cancer subtypes. PeerJ 7: e8049 DOI 10.7717/peerj.8049.

Pubmed: Author and Title

Google Scholar: Author Only Title Only Author and Title

Arroyo JD, Chevillet JR, Kroh EM, Ruf IK, Pritchard CC, Gibson DF, Mitchell PS, Bennett CF, Pogosova-Agadjanyan EL, Stirewalt DL, Tait JF, Tewari M. 2011. Argonaute2 complexes carry a populationof circulating microRNAs independent of vesicles in human plasma. Proceedings of the National Academy of Sciences of the United States of America 108: 5003-5008 DOI 10.1073/pnas.1019055108.

Pubmed: Author and Title

Google Scholar: Author Only Title Only Author and Title

Arteaga-Vazquez M, Caballero-Perez J, Vielle-Calzada JP. 2006. A family of microRNAs present in plants and animals. Plant Cell 18: 3355-3369 DOI 10.1105/tpc.106.044420.

Pubmed: Author and Title

Google Scholar: Author Only Title Only Author and Title

Atambayeva S, Niyazova R, Ivashchenko A, Pyrkova A, Pinsky l, Akimniyazova A, Labeit S. 2017. The Binding Sites of miR-619-5p in the mRNAs of Human and Orthologous Genes. BMC Genomics 18: 428. DOI 10.1186/s12864-017-3811-6.

Pubmed: Author and Title

Google Scholar: Author Only Title Only Author and Title

Axtell MJ, Westholm JO, Lai EC. 2011. Vive la difference: biogenesis and evolution of microRNAs in plants and animals. Genome Biology 12: 1-13. DOI 10.1186/gb-2011-12-4-221.

Pubmed: Author and Title

Google Scholar: Author Only Title Only Author and Title

Balyan S, Kumar M, Mutum R, Raghuvanshi U, Agarwal P, Mathur S, Raghuvanshi S. 2017. Identification of miRNAmediated drought responsive multi-tiered regulatory network in drought tolerant rice, Nagina 22. Scientific Reports 7: 15446 DOI 10.1038/s41598-01715450-1.

Pubmed: Author and Title

Google Scholar: Author Only Title Only Author and Title

Bang C, Thum T. 2012. Exosomes: new players in cell-cell communication. The International Journal of Biochemistry \& Cell Biology 44:2060-2064 DOI 10.1016/j.biocel.2012.08.007.

Pubmed: Author and Title

Google Scholar: Author Only Title Only Author and Title

Bari A, Orazova S, Ivashchenko A 2013. miR156- and miR171-binding sites in the protein-coding sequences of several plant genes.

BioMed Research International 2013: 1-7 DOI 10.1155/2013/307145.

Pubmed: Author and Title

Google Scholar: Author Only Title Only Author and Title

Bari A, Sagaidak I, Pinskii I, Orazova S, Ivashchenko A 2014. Binding of miR396 to mRNA of Genes Encoding Growth-Regulating Transcription Factors of Plants. Russian Journal of Plant Physiology 61: 807-810 DOI 10.1134/S1021443714050033.

Pubmed: Author and Title

Google Scholar: Author Only Title Only Author and Title

Buck AH, Coakley G, Simbari F, McSorley HJ, Quintana JF, Le Bihan T, Kumar S, Abreu-Goodger C, Lear M, Harcus Y, Ceroni A, Babayan SA, Blaxter M, Ivens A, Maizels RM. 2014. Exosomes secreted by nematode parasites transfer small RNAs to mammalian cells and modulate innate immunity. Nature Communications 5: 5488 DOI 10.1038/ncomms6488.

Pubmed: Author and Title

Google Scholar: Author Only Title Only Author and Title

Chen J, Li L. 2018. Multiple Regression Analysis Reveals MicroRNARegulatory Networks in Oryza sativa under Drought Stress.

International Journal of Genomics 2018: 1-12 DOI 10.1155/2018/9395261.

Pubmed: Author and Title

Google Scholar: Author Only Title Only Author and Title

Chiang K, Shu J, Zempleni J, Cui J. 2015. Dietary MicroRNA Database (DMD): An Archive Database and Analytic Tool for Food-Borne microRNAs. PLOS One 10: 6 DOI 10.1371/journal.pone.0128089.

Pubmed: Author and Title

Google Scholar: Author Only Title Only Author and Title

Chin AR, Fong MY, Somlo G. 2016. Cross-kingdom inhibition of breast cancer growth by plant miR159. Cell Research 26: 217-228 DOI 10.1038/cr.2016.13.

Pubmed: Author and Title

Google Scholar: Author Only Title Only Author and Title

Cimini S, Gualtieri C, Macovei A, Balestrazzi A De Gara L, Locato V. 2019. Redox Balance-DDR-miRNA Triangle: Relevance in Genome Stability and Stress Responses in Plants. Frontiers in Plant Science 10: 989 DOI 10.3389/fpls.2019.00989.

Pubmed: Author and Title

Google Scholar: Author Only Title Only Author and Title 
Cong L, Zhao Y, Pogue A, Lukiw WJ. 2018. Role of microRNA(miRNA) and Viroids in Lethal Diseases of Plants and Animals. Potential Contribution to Human Neurodegenerative Disorders. Biochemistry (Moscow) 83: 1018-1029 DOI 10.1134/S0006297918090031.

Pubmed: Author and Title

Google Scholar: Author Only Title Only Author and Title

Cui J, Zhou B, Ross SA, Zempleni J. 2017. Nutrition, microRNAs, and Human Health. Advances in Nutrition 8: 105-112 DOI

10.3945/an.116.013839.

Pubmed: Author and Title

Google Scholar: Author Only Title Only Author and Title

Dai X, Zhuang Z, Zhao P. 2011. Computational Analysis of miRNA Targets in Plants: Current Status and Challenges. Briefings in Bioinformatics 12: 115-121 DOI 10.1093/bib/bbq065.

Pubmed: Author and Title

Google Scholar: Author Only Title Only Author and Title

Denzer K, Eijk MV, Kleijmeer MJ, Jakobson E, Groot CD, Geuze HJ. 2000. Follicular

dendritic cells carry MHC Class II-expressing microvesicles at their surface. Journal

of Immunology 165:1259-1265 DOI 10.4049/jimmunol.165.3.1259.

Pubmed: Author and Title

Google Scholar: Author Only Title Only Author and Title

Escrevente C, Keller S, Altevogt P, Costa J. 2011. Interaction and uptake of exosomes by ovarian cancer cells. BMC Cancer 11: 108 DOI 10.1186/1471-2407-11-108.

Pubmed: Author and Title

Google Scholar: Author Only Title Only Author and Title

Garg A Heinemann U. 2018. Anovel form of RNA double helix based on G-U and C.A+ wobble base pairing. RNA24: 209-218 DOI 10.1261/rna.064048.117.

Pubmed: Author and Title

Google Scholar: Author Only Title Only Author and Title

Gopinath MS. 2019. Dietary non-coding RNAs from plants: Fairy tale or treasure? Non-coding RNAResearch 4: 63-68 DOI 10.1016/j.ncrna.2019.02.002.

Pubmed: Author and Title

Google Scholar: Author Only Title Only Author and Title

Hou D, He F, Ma L, Cao M, Zhou Z, Wei Z, Xue Y, Sang X, Chong H, Tian C, Zheng S, Li J, Zen K, Chen X, Hong Z, Zhang CY, Jiang X. 2018. The potential atheroprotective role of plant MIR156a as a repressor of monocyte recruitment on inflamed human endothelial cells. The Journal of Nutritional Biochemistry 57: 197-205 DOI 10.1016/j.jnutbio.2018.03.026.

Pubmed: Author and Title

Google Scholar: Author Only Title Only Author and Title

Hoy AM, Buck AH. 2012. Extracellular small RNAs: what, where, why? Biochemical Society Transactions 40: 886-890 DOI 10.1042/BST20120019.

Pubmed: Author and Title

Google Scholar: Author Only Title Only Author and Title

Ivashchenko AT, Pyrkova AY, Niyazova RY, Alybayeva A, Baskakov K. 2016. Prediction of miRNA binding sites in mRNA Bioinformation 12: 237-240. DOI 10.6026/97320630012237.

Pubmed: Author and Title

Google Scholar: Author Only Title Only Author and Title

Javed M, Solanki M, Sinha A, Shukla LI. 2017. Position Based Nucleotide Analysis of miR168 Family in Higher Plants and its Targets in Mammalian Transcripts. Microrna 6: 136-142 DOI 10.2174/2211536606666170215154151.

Pubmed: Author and Title

Google Scholar: Author Only Title Only Author and Title

Jia L, Zhang D, Qi X, Ma B, Xiang Zh, He N, Zhang J. 2014. Identification of the Conserved and Novel miRNAs in Mulberry by HighThroughput Sequencing. PLOS One 9: 8 DOI 10.1371/journal.pone.0104409.

Pubmed: Author and Title

Google Scholar: Author Only Title Only Author and Title

Jonathan WS, Andrew EH, Stephanie KI, Aaron LB, Stephen YC. 2013. Ineffective delivery of diet-derived microRNAs to recipient animal organisms. RNA Biology 10: 1107-1116 DOI 10.4161/rna.24909.

Pubmed: Author and Title

Google Scholar: Author Only Title Only Author and Title

Jones Buie JN, Goodwin AJ, Cook JA, Halushka PV, Fan H. 2016. The role of miRNAs in cardiovascular disease risk factors.

Atherosclerosis 254: 271-281 DOI 10.1016/j.atherosclerosis.2016.09.067.

Pubmed: Author and Title

Google Scholar: Author Only Title Only Author and Title 
Kool ET. 2001. Hydrogen bonding, base stacking, and steric effects in DNA replication. Annual Review of Biophysics and Biomolecular Structure 30: 1-22 DOI 10.1146/annurev.biophys.30.1.1.

Pubmed: Author and Title

Google Scholar: Author Only Title Only Author and Title

Lang C, Karunairetnam S, Lo KR, Kralicek AV, Crowhurst RN, Gleave AP, MacDiarmid RM, Ingram JR. 2019. Common Variants of the Plant microRNA168a Exhibit Differing Silencing Efficacy for Human Low-Density Lipoprotein Receptor Adaptor Protein 1 (LDLRAP1). Microrna 8: 166-170 DOI 10.2174/2211536608666181203103233.

Pubmed: Author and Title

Google Scholar: Author Only Title Only Author and Title

Leontis NB, Stombaugh J, Westhof E. 2002. The non-Watson-Crick base pairs and their associated isostericity matrices. Nucleic Acids Research 30: 3497-3531 DOI 10.1093/nar/gkf481.

Pubmed: Author and Title

Google Scholar: Author Only Title Only Author and Title

Liang H, Huang L, Cao J, Zen K, Chen X, Zhang CY. 2012. Regulation of mammalian gene expression by exogenous microRNAs. Wiley Interdisciplinary Reviews-RNA3: 733-742 DOI 10.1002/wrna.1127.

Pubmed: Author and Title

Google Scholar: Author Only Title Only Author and Title

Liang H, Zen K, Zhang J, Zhang CY, Chen X. 2013. New roles for microRNAs in cross-species communication. RNABiology 10 : $367-370$ DOI 10.4161/rna.23663.

Pubmed: Author and Title

Google Scholar: Author Only Title Only Author and Title

Liang H, Zhang S, Fu Z, Wang Y, Wang N, Liu Y, Zhao C, Wu J, Hu Y, Zhang J, Chen X, Zen K, Zhang CY. 2015. Effective detection and quantification of dietetically absorbed plant microRNAs in human plasma. The Journal of Nutritional Biochemistry 26: 505-512 DOI

10.1016/j.jnutbio.2014.12.002.

Pubmed: Author and Title

Google Scholar: Author Only Title Only Author and Title

Liu W, Meng J, Cui J, Luan Yu. 2017. Characterization and Function of MicroRNAs in Plants. Frontiers in Plant Science 8. DOI

10.3389/fpls.2017.02200.

Pubmed: Author and Title

Google Scholar: Author Only Title Only Author and Title

Lukasik A Zelenkiewicz P. 2016. Plant microRNAs - novel players in natural medicine? The International Journal of Molecular Sciences 18: 1-16 DOI 10.3390/ijms18010009.

Pubmed: Author and Title

Google Scholar: Author Only Title Only Author and Title

Luo Y, Wang P, Wang X, Wang Y, Mu Z, Li Q, Fu Y, Xiao J, Li G, Ma Y, Gu Y, Jin L, Ma J, Tang Q, Jiang A, Li X, Li M. 2017. Detection of dietetically absorbed maize-derived microRNAs in pigs. Scientific Reports 7: 1-10 DOI 10.1038/s41598-017-00488-y.

Pubmed: Author and Title

Google Scholar: Author Only Title Only Author and Title

Makarova JA, Shkurnikov MU, Wicklein D, Lange T, Samatov TR, Turchinovich AA, Tonevitsky AG. 2016. Intracellular and extracellular microRNA: an update on localization and biological role. Progress in Histochemistry and Cytochemistry 51: 33-49 DOI

10.1016/j.proghi.2016.06.001.

Pubmed: Author and Title

Google Scholar: Author Only Title Only Author and Title

Malloci M, Perdomo L, Veerasamy M, Andriantsitohaina R, Simard G, Martinez MC. 2018. Extracellular vesicles: mechanisms in human health and disease. Antioxidants \& Redox Signaling 30: 813-856 DOI 10.1089/ars.2017.7265.

Pubmed: Author and Title

Google Scholar: Author Only Title Only Author and Title

Melnik BC, John SM, Schmitz G. 2014. Milk: an exosomal microRNAtransmitter promoting thymic regulatory T cell maturation preventing the development of atopy? The Journal of Translational Medicine 12: 1-11 DOI 10.1186/1479-5876-12-43.

Pubmed: Author and Title

Google Scholar: Author Only Title Only Author and Title

Millar AA, Waterhouse PM. 2005. Plant and animal microRNAs: similarities and differences. Functional \& Integrative Genomics 5: 129135 DOI 10.1007/s10142-005-0145-2.

Pubmed: Author and Title

Google Scholar: Author Only Title Only Author and Title

Mondal T, Panda A, Rawal H, Sharma T. 2018. Discovery of microRNA-target modules of African rice (Oryza glaberrima) under salinity stress. Scientific Reports 8: 570 DOI 10.1038/s41598-017-18206-z.

Pubmed: Author and Title

Google Scholar: Author Only Title Only Author and Title

Montecalvo A, Larregina AT, Shufesky WJ, Stolz DB, Sullivan ML, Karlsson JM, Baty CJ, Gibson GA, Erdos G, Wang Z, Milosevic J, 
Tkacheva OA, Divito SJ, Jordan R, Lyons-Weiler J, Watkins SC, Morelli AE. 2012. Mechanism of transfer of functional microRNAs between mouse dendritic cells via exosomes. Blood 119: 756-766 DOI 10.1182/blood-2011-02-338004.

Pubmed: Author and Title

Google Scholar: Author Only Title Only Author and Title

Moran Y, Agron M, Praher D, Technau U. 2017. The evolutionary origin of plant and animal microRNAs. Nature Ecology \& Evolution 1: 1-22 DOI 10.1038/s41559-016-0027.

Pubmed: Author and Title

Google Scholar: Author Only Title Only Author and Title

Nair SK, Wang N, Turuspekov Y, Pourkheirandish M, Sinsuwongwat S, Chen G, Sameri M, Tagiri A, Honda I, Watanabe Y, Kanamori H, wicker T, Stein N, Nagamura Y, Matsumoto T, Komatsuda T. 2010. Cleistogamous flowering in barley arises from the suppression of microRNAguided HvAP2 mRNA cleavage. Proceedings of the National Academy of Sciences of the United States of America 107: 490495 DOI 10.1073/pnas.0909097107.

Pubmed: Author and Title

Google Scholar: Author Only Title Only Author and Title

Perge P, Nagy Z, Decmann A, Igaz I, Igaz P. 2017. Potential relevance of microRNAs in inter-species epigenetic communication, and implications for disease pathogenesis. RNABiology. 14: 391-401 DOI 10.1080/15476286.2016.1251001.

Pubmed: Author and Title

Google Scholar: Author Only Title Only Author and Title

Pirro S, Minutolo A, Galgani A, Potesta M, Colizzi V, Montesano C. 2016. Bioinformatics prediction and experimental validation of microRNAs involved in cross-kingdom interaction. The Journal of Computational Biology 23: 976-989 DOI 10.1089/cmb.2016.0059.

Pubmed: Author and Title

Google Scholar: Author Only Title Only Author and Title

Pogue A, Clement C, Hill JM, Lukiw WJ. 2014. Evolution of microRNA(miRNA) structure and function in plants and animals: relevance to aging and disease. Journal of Aging Science 2: 1-12 DOI 10.4172/2329-8847.1000119.

Pubmed: Author and Title

Google Scholar: Author Only Title Only Author and Title

Redis RS, Calin S, Yang Y, You MJ, Calin GA 2012. Cell-to-cell miRNA transfer:

from body homeostasis to therapy. Pharmacology \& Therapeutics 136:169-174

DOI 10.1016/j.pharmthera.2012.08.003.

Rutter BD, Innes RW. 2018. Extracellular vesicles as key mediators of plant-microbe interactions. Current Opinion in Plant Biology 44: 16-22 DOI 10.1016/j.pbi.2018.01.008.

Pubmed: Author and Title

Google Scholar: Author Only Title Only Author and Title

Stephen Y, Snow J. 2017. Formidable challenges to the notion of biologically important roles for dietary small RNAs in ingesting mammals. Genes and Nutrition 12: 13 DOI 10.1186/s12263-017-0561-7.

Pubmed: Author and Title

Google Scholar: Author Only Title Only Author and Title

Thery C, Ztvogel L, Amigorena S. 2002. Exosomes: composition, biogenesis and

function. Nature Reviews Immunology 2:569-579 DOI 10.1038/nri855.

Valadi H, Ekström K, Bossios A, Sjöstrand M, Lee JJ, Lötvall JO. 2007. Exosomemediated transfer of mRNAs and microRNAs is a novel mechanism of genetic

exchange between cells. Nature Cell Biology 9:654-659 DOI 10.1038/ncb1596.

Pubmed: Author and Title

Google Scholar: Author Only Title Only Author and Title

van der Grein SG, Nolte-'t Hoen EN. 2014. "Small Talk" in the Innate Immune System via RNA-Containing Extracellular Vesicles.

Frontiers in Immunology 5: 542 DOI 10.3389/fimmu.2014.00542.

Pubmed: Author and Title

Google Scholar: Author Only Title Only Author and Title

Vaucheret H, Chupeau Y. 2012. Ingested plant miRNAs regulate gene expression in animals. Cell Research 1: 3-5 DOI

10.1038/cr.2011.164.

Pubmed: Author and Title

Google Scholar: Author Only Title Only Author and Title

Wagner AE, Piegholdt S, Ferraro M, Pallauf K, Rimbach G. 2015. Food derived microRNAs. Food \& Function 6: 714-718 DOI 10.1039/c4fo01119h.

Pubmed: Author and Title

Google Scholar: Author Only Title Only Author and Title

Wang Yo, Li L, Tang Sh, Liu J, Zhang H, Zhi H, Jia G, Diao X. 2016. Combined small RNAand degradome sequencing to identify miRNAs 
and their targets in response to drought in foxtail millet. BMC Genomics 17: 57 DOI 10.1186/s12863-016-0364-7.

Pubmed: Author and Title

Google Scholar: Author Only Title Only Author and Title

Xiao J, Feng S, Wang X, Long K, Luo Y, Wang Y, Ma J, Tang Q, Jin L, Li X, Li M. 2018. Identification of exosome-like nanoparticlederived microRNAs from 11 edible fruits and vegetables. PeerJ 6: e5186 DOI 10.7717/peerj.5186.

Pubmed: Author and Title

Google Scholar: Author Only Title Only Author and Title

Xie W, Weng A, Melzig MF. 2016. MicroRNAs as new bioactive components in medicinal plants. Planta Medica 82: 1153-1162. DOI 10.1055/s-0042-108450.

Pubmed: Author and Title

Google Scholar: Author Only Title Only Author and Title

Yurikova OY, Aisina DE, Niyazova RE, Atambayeva SA, Labeit S, Ivashchenko AT. 2019. The Interaction of miRNA-5p and miRNA-3p with the mRNAs of Orthologous Genes. Mol Biol (Mosk) 53: 692-704 DOI 10.1134/S0026898419040189.

Pubmed: Author and Title

Google Scholar: Author Only Title Only Author and Title

Zempleni J, Aguilar-Lozano A, Sadri M, Sukreet S, Manca S, Wu D, Zhou F, Mutai E. 2017. Biological Activities of Extracellular Vesicles and Their Cargos from Bovine and Human Milk in Humans and Implications for Infants. The Journal of Nutrition 147: 3-10 DOI

10.3945/jn.116.238949.

Pubmed: Author and Title

Google Scholar: Author Only Title Only Author and Title

Zhang L, Chen T, Yin Yo, Zhang Ch, Zhang Yo. 2019. Dietary microRNA-ANovel Functional Component of Food. Advances in Nutrition 10: 711-721. DOI 10.1093/advances/nmy127.

Pubmed: Author and Title

Google Scholar: Author Only Title Only Author and Title

Zhang L, Hou D, Chen X, Li D, Zhu L, Zhang Y, Li J, Bian Z, Liang X, Cai X, Yin Y, Wang C, Zhang T, Zhu D, Zhang D, Xu J, Chen Q, Ba Y, Liu J, Wang Q, Chen J, Wang J, Wang M, Zhang Q, Zhang J, Zen K, Zhang CY. 2012. Exogenous plant MIR168a specifically targets mammalian LDLRAP1: evidence of cross-kingdom regulation by microRNA Cell Research 22: 107-126 DOI 10.1038/cr.2011.158.

Pubmed: $\underline{\text { Author and Title }}$

Google Scholar: Author Only Title Only Author and Title

Zhang H, Li Y, Liu Y, Liu H, Wang H, Jin W, Zhang Y, Zhang C, Xu D. 2016. Role of plant microRNAin cross-species regulatory networks of humans. BMC Systems Biology 10: 1-10 DOI 10.1186/s12918-016-0292-1.

Pubmed: Author and Title

Google Scholar: Author Only Title Only Author and Title

Zhao Q, Liu Yu, Zhang N, Hu M, Zhang H, Joshi T, Xu D. 2018. Evidence for plant-derived xenomiRs based on a large-scale analysis of public small RNA sequencing data from human samples. PLOS One 13: 6 DOi 10.1371/journal.pone.0187519.

Pubmed: Author and Title

Google Scholar: Author Only Title Only Author and Title

ZhaoY, Cong L, Lukiw WJ. 2018. Plant and animal microRNAs (miRNAs) and their potential for interkingdom communication. Cellular and Molecular Neurobiology 38: 133-140 DOI 10.1007/s10571-017-0547-4.

Pubmed: Author and Title

Google Scholar: Author Only Title Only Author and Title

Zhou Z, Li X, Liu J, Dong L, Chen Q, Liu J, Kong H, Zhang Q, Qi X, Hou D, Zhang L, Zhang G, Liu Y, Zhang Y, Li J, Wang J, Chen X, Wang H, Zhang J, Chen H, Zen K, Zhang CY. 2015. Honeysuckle-encoded atypical microRNA2911 directly targets influenza Aviruses. Cell research 1: 39-49 DOI 10.1038/cr.2014.130.

Pubmed: Author and Title

Google Scholar: Author Only Title Only Author and Title 